\title{
Effects of tourist visitation and supplementary feeding on fish assemblage composition on a tropical reef in the Southwestern Atlantic
}

\author{
Martina Di Iulio Ilarri, Allan Tainá de Souza, Paulo Roberto de Medeiros, Renato Grotta \\ Grempel and Ierecê Maria de Lucena Rosa
}

The effects of tourist visitation and food provisioning on fish assemblages were assessed by visual censuses (stationary technique) carried out in a tropical reef in Northeastern Brazil. Comparisons of species abundance, richness, equitability, and trophic structure in the presence (PT) and absence (AT) of tourists suggest that tourist visitation and supplementary food influenced the structure of the fish assemblage, as follows: (a) diversity, equitability and species richness were significantly higher on the AT period, while the abundance of a particular species was significantly higher during PT; (b) trophic structure differed between the AT and PT periods, omnivores being more abundant during the latter period, while mobile invertivores, piscivores, roving herbivores and territorial herbivores were significantly more abundant on AT. Reef tourism is increasingly being regarded as an alternative to generate income for human coastal communities in the tropics. Therefore, closer examination of the consequences of the various components of this activity to reef system is a necessary step to assist conservation and management initiatives.

Os efeitos da visitação turística e da alimentação suplementar sobre a ictiocenose foram avaliados por meio de censos visuais (técnica estacionária) em um recife tropical no nordeste do Brasil. Comparações entre a abundância das espécies, riqueza, equitabilidade e estrutura trófica na presença (PT) e na ausência (AT) de turistas sugerem que a visitação turística e a alimentação suplementar influenciam a estrutura da ictiocenose, como segue: (a) diversidade, equitabilidade e riqueza de espécies foram significativamente maiores no período AT, enquanto a abundância de uma única espécie foi significativamente maior durante o período PT; (b) a estrutura trófica foi diferente entre os períodos AT e PT, com os onívoros sendo mais abundantes no último período, enquanto invertívoros móveis, piscívoros, herbívoros errantes e herbívoros territoriais foram significativamente mais abundantes no período AT. O turismo em ambientes recifais é cada vez mais uma opção na geração de renda para diversas comunidades costeiras nos trópicos. Conseqüentemente, investigações mais detalhadas sobre as conseqüências dos vários componentes desta atividade sobre o sistema recifal são necessárias para subsidiar iniciativas de manejo e conservação.

Key words: Fish behavior, Tourism, Human impact, Northeastern Brazil, Abudefduf saxatilis.

\section{Introduction}

Tourism is the fastest growing economic activity of the world, natural area visitation being its most rapidly growing segment. These areas are visited to "get away from it all", and this involves many recreational activities (Newsome et al., 2002).

Wildlife viewing and equivalent types of nature-based tourism are often promoted as the option of choice for the direct use of wildlife (Honey, 1999), a view that is increasingly being embraced by the promoters of reef tourism - a form of marine recreational tourism that according to Alevizon (2004), generally encompasses activities to "facilitate client viewing and/or other human-wildlife interactions, such as touching and handling".
Food provisioning by tourists is among the different forms of human-wildlife interaction in reef areas (Newsome et al., 2004), and has been considered a source of disruption or alteration to the natural distribution and abundance patterns of marine fishes (see Perrine, 1989; Cole, 1994; Hawkins et al., 1999), as well as of the "fed" individuals and the ecosystems of which they are part of (Alevizon, 2004). Furthermore, Newsome et al. (2002) have drawn attention to a real danger of wildlife becoming accustomed to, and dependent on humans for food in tourism areas, due to the potentially serious health and behavioral implications, particularly for a rare species or a species with a restricted population.

Despite the evidence that visitation may be harmful to overall reef communities when not organized and/or controlled (see Salvat, 1987; Roberts \& Harriot, 1994; Prior et

Departamento de Sistemática e Ecologia, Centro de Ciências Exatas e da Natureza, Universidade Federal da Paraíba, 58059-900 João Pessoa, Paraíba, Brazil.martinailarri@gmail.com 
al., 1995; Allison, 1996; Harriot et al., 1997), reef tourism is often regarded as an important income source to fishermen communities where fisheries have declined (Cesar, 1996; Vogt, 1996), while helping to protect reefs by providing an incentive to their conservation (Hawkins et al., 1999). In fact, different human coastal communities in the tropics are already in the process of shifting from dependence on fishing to dependence on tourism (e.g., Diedrich, 2007).

In this paper we examine the relationships between fish assemblage composition, tourist visitation, and food provisioning in a tropical reef in Northeast Brazil. The study site (Picãozinho reef) is a highly sought after tourist destination where fish are usually fed by visitors with bread, cookies or fish food (MII, pers. observ.).

Our main goal was to assess the effects of supplementary feeding on the reef fish assemblage structure by comparing its abundance and diversity between two periods (presence versus absence of visitors).

\section{Material and Methods}

\section{Study site}

Picãozinho $\left(07^{\circ} 06^{\prime} 15^{\prime \prime} \mathrm{S}, 34^{\circ} 48^{\prime} 45^{\prime \prime} \mathrm{W}\right)$ is a coastal tropical reef with a maximum depth of $6 \mathrm{~m}$, located about $1500 \mathrm{~m}$ off the coast of João Pessoa, Paraíba, Northeastern Brazil. The seascape in the study area is mostly characterized by seaweeds such as Caulerpa racemosa, Halimeda opuntia and Dyctiopteris delicatula, while corals such as Palythoa caribaeorum, Zoanthus spp., Siderastrea stellata and Musimilia hartii are the dominant components of the benthic community (Young, 1986; Medeiros et al., 2007). Recreational tourism has been occurring at Picãozinho reef since the mid 80's, without any supervision. Supplementary feeding, trampling, boat anchoring and water turbidity increase are problems commonly observed in the area during visitation (Ilarri et al., 2007).

The fish assemblage was assessed using the stationary visual census method adapted from Bohnsack \& Bannerot (1986). At each point sampled, the numerical abundance of active reef-associated fishes was estimated. Sites were randomly chosen within the area mostly visited by tourists, from a set of sites with comparable zonation and tourist influence. All censuses were carried out at low tide $(-0.2$ to $0.3 \mathrm{~m})$. In order to avoid bias due to tidal amplitude, censuses were conducted within small intervals from one another.

Visual censuses were carried out from February 2006 through August 2006 (dry season), at depths between 0.5 and $3 \mathrm{~m}$. In total we performed 72 censuses ( $2.5 \mathrm{~m}$ radius), 36 during tourist visitation (PT) and 36 when tourists were not present (AT). Prior to visitation, samples were classified as AT, and subsequently as PT. No distinction was made between weekdays and weekends, as tourism took place throughout the week at the reef. The reef was open for tourist visitation while the census data of PT were being undertaken and for the AT, we sampled the exact same area.

Numerical abundances of targeted species were determined by counting all individuals sighted, while size (total length) of individual fish was visually estimated and assigned to one of the following five size classes: $1-5 \mathrm{~cm}, 6-10 \mathrm{~cm}, 11-15 \mathrm{~cm}$, $16-20 \mathrm{~cm}$ and $21-25 \mathrm{~cm}$. Species were visually identified in situ or through underwater photographs, which were compared with the descriptions found in Humann \& Deloach (2002) and Carvalho-Filho (1999).

Species were grouped according to trophic categories well-established in the literature (Randall, 1967; Hobson, 1975; Ferreira et al., 2004), as follows: carnivores, mobile invertivores, omnivores, piscivores, planktivores, roving herbivores, sessile invertivores, and territorial herbivores. Statistical analyses were performed with the program Statistica version 5.1 (Statsoft Corp., United States).

Species richness is expressed as the number of species (S), while diversity and homogeneity were estimated by the Shannon Wiener's diversity index $\left(\mathrm{H}^{\prime}\right)$, using the software PRIMER 5.0. Since most data departed from normality (Shapiro-Wilk's W test), comparisons between PT and AT were made using the non-parametric Mann-Whitney U-test (in some cases Z-adjusted values and P-values were considered). A non-metric multidimensional scaling (MDS) was applied to the similarity matrix to visualize the relationships among samples within PT and AT, considering the abundance data of all fish census replicates. Prior to the analysis, a double square-root transformation was applied to the abundance in order to normalize and avoid skew in the data set. Additionally an analysis of similarity percentages of particular species (SIMPER) was conducted to examine potential differences in fish assemblage structure between PT and AT, following Field et al. (1982). Essentially, this procedure computes the average dissimilarity between all pairs of inter-group (PT vs. AT) periods, and then breaks this average down into the separate contributions from each species. These analyses were carried out using the software PRIMER 5.0.

\section{Results}

Throughout the study, 5006 specimens (33 species, 20 families), were sighted (Table 1), 3003 of which (22 species, 14 families) during visitation by tourists. The most species rich families were Haemulidae (4 species), Pomacentridae (3) and Acanthuridae (3), and the 10 most frequent species, in decreasing order, were Abudefduf saxatilis, Stegastes fuscus, Sparisoma spp., Haemulon parra, Halichoeres brasiliensis, Acanthurus coeruleus, Haemulon aurolineatum, Ophioblennius trinitatis, Stegastes variabilis and Coryphopterus glaucofraenum. Occasional and rare species ( $<10 \%$ of occurrence) represented $0.42 \%$ of all fishes recorded. The most abundant species were Abudefduf saxatilis $(\mathrm{n}=2482)$ and Stegastes fuscus $(\mathrm{n}=377)$, which together represented $86.5 \%$ of all individuals recorded.

During the absence of tourists (AT), 1710 specimens (29 species, 17 families) were recorded, the most species rich families being Haemulidae ( 5 species), Pomacentridae (3) and Acanthuridae (3). The 10 most frequent species, in decreasing order, were Abudefduf saxatilis, Stegastes fuscus, 
Sparisoma spp., Halichoeres brasiliensis, Haemulon parra, Acanthurus coeruleus, Ophioblennius trinitatis, Halichoeres poeyi, Caranx latus, and Acanthurus chirurgus. Occasional and rare species $(<10 \%$ of occurrence) represented $1.22 \%$ of all fishes recorded. The most abundant species were Abudefduf saxatilis $(\mathrm{n}=629)$ and Stegastes fuscus $(\mathrm{n}=389)$, which together made up $59.5 \%$ of all individuals recorded while the other 27 species represented $40.5 \%$.

Of the 33 species recorded, 18 were found at PT and AT periods, while four were found exclusively during PT (Synodus intermedius, Scorpaena sp., Haemulon squamipinna, and Bothus lunatus) and 12 were found exclusively during AT (Mugil curema, Holocentrus adscencionis, Myripristis jacobus, Ocyurus chysurus, Anisotremus moricandi, Pseudupeneus maculatus, Haemulon plumieri, Chaetodon striatus, Gobionellus stomatus, Acanthurus bahianus, and Sphoeroides testudineus) (Table 1).

The abundance of seven species was significantly different between PT and AT periods, most of them being more abundant when no visitation was taking place (Table 1). Only Abudefduf saxatilis was significantly more abundant during PT $(Z=4.93 ; p<0,001)$. The other six species were more abundant during AT, as follows: Acanthurus chirurgus $(\mathrm{Z}=$ $-2.33 ; \mathrm{p}<0.05)$, Anisotremus virginicus $(\mathrm{Z}=-3.18 ; \mathrm{p}<0.01)$, Caranx latus $(\mathrm{Z}=-1.96 ; \mathrm{p}<0.05)$, Epinephelus adscencionis $(\mathrm{Z}=-2.03 ; \mathrm{p}<0.05)$, Halichoeres poeyi $(\mathrm{Z}=-2.64 ; \mathrm{p}<0.01)$, and Sparisoma spp. $(\mathrm{Z}=-2.42 ; \mathrm{p}<0.05)$.

The MDS analysis revealed some segregation between the periods, with most of the assemblage samples from PT located in the middle of the plot, indicating that the samples which are closer together are less distinct; conversely, the AT samples exhibited a more heterogeneous pattern with dissimilarity between samples during tourist visitation at the study site (Fig. 1). The SIMPER analysis revealed that $A$. saxatilis contributed more to the dissimilarity $(61.73 \%)$ than any other species (Table 2).

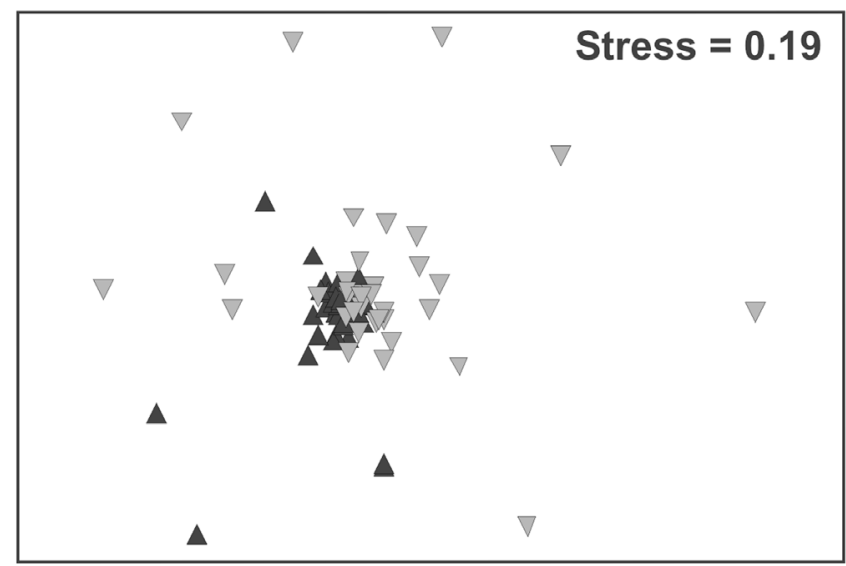

Fig. 1. Non-Metric Multi-Dimensional Scaling (MDS) plot of fish assemblages samples of the Picãozinho reef in each of the two studied situations. Dark triangles $=$ PT (presence of tourists) and light triangles $=\mathrm{AT}$ (absence of tourists).
A comparison of the fish assemblage attributes indicated that fish diversity, equitability and richness were lower in the presence tourist, while only the total number of fish was higher (Table 3 ).

The mean number of individuals in each trophic category differed between PT and AT periods as follows: omnivores were nearly four times more abundant during PT than during AT, while five out of the eight trophic categories recorded (mobile invertivores, omnivores, piscivores, roving herbivores and territorial herbivores) exhibited significant differences between periods (Table 4).

During PT, fishes in the $6-10 \mathrm{~cm}$ size class comprised over $31.95 \%$ of the total abundance. The $11-15 \mathrm{~cm}$ size class contained $30.36 \%$ of the fishes, while the $1-5 \mathrm{~cm}$ size class made up over $26.11 \%$. During AT, fishes in the $6-10 \mathrm{~cm}$ size class made up over $32.15 \%$ of the fishes, the $1-5 \mathrm{~cm}$ size class contained $27.38 \%$ while the $11-15 \mathrm{~cm}$ size class constituted $24.24 \%$ of the total abundance. The least abundant size class both during PT and AT was the $21-35 \mathrm{~cm}$ class, contributing only $0.73 \%$ and $1.21 \%$, respectively. The abundance of three size classes $(6-10 \mathrm{~cm}, 11-15 \mathrm{~cm}$ and $16-20 \mathrm{~cm})$ was significantly higher at PT period, while the other size classes showed no statistical differences between the periods (Table 5).

\section{Discussion}

The consequences of ill-planned, uncontrolled recreational tourism to coastal ecosystems have been increasingly acknowledged, however there have been few attempts to specifically examine the possible effects of supplementary feeding on reef fish assemblages. Our findings corroborated the results of previous studies (Cole, 1994; Millazzo et al., 2005), which have shown that food provisioning plays a role in shaping the structure of the fish assemblages. The consistent discrepancies in fish abundance, diversity, evenness and size classes abundance between the AT and PT periods at the study site were mainly related to the extremely high abundance of a single species (Abudefduf saxatilis), commonly known as sergeant major. Although usually abundant in many tropical Atlantic reefs (Humann \& Deloach, 2002), A. saxatilis is seldom found in high abundances on Brazilian Northern reefs (Molina et al., 2006). Due to its generalist omnivorous feeding habits, that species is able to feed on a diverse array of food items and normally shows clear patterns of opportunistic behavior (Deloach \& Humann, 1999), being also capable of shifting between food sources as a result of seasonal and historical environmental disturbances (Ferreira et al., 2004).

At Picãozinho reef, $A$. saxatilis was the only fish species observed feeding on the supplementary food offered by tourists, while the majority of the other species vanished during visitations. Over the years, the supplementary food may have benefited the population of $A$. saxatilis, thus leading to the high densities found in our study. This could be related to behavioral aspects of this species, since aggressive species tend to benefit from artificial feeding, dominating over non-aggressive species (Orams, 2002). Such changes have the potential to alter 
Table 1. Trophic categories, number of individuals $(\mathrm{N})$, frequency and relative abundance (\% of total number of individuals) of reef fishes in the two periods, at presence of tourists (PT) and at absence of tourists (AT). The families are listed in phylogenetic order, following Nelson (2006); species are alphabetically organized within each family. Rov. Herbiv. = Roving herbivore; Mob. Invert. = Mobile Invertivore; Plankt. = Planktivore; Ter. Herbiv. $=$ Territorial herbivore.

\begin{tabular}{|c|c|c|c|c|c|c|c|}
\hline \multirow[b]{2}{*}{ Family/Species } & \multirow[b]{2}{*}{ Trophic group } & \multicolumn{3}{|c|}{ Presence of tourists $(\mathrm{PT})$} & \multicolumn{3}{|c|}{ Absence of tourists (AT) } \\
\hline & & $\mathrm{N}$ & Frequency $\%$ & Abundance $\%$ & $\mathrm{~N}$ & Frequency $\%$ & Abundance $\%$ \\
\hline \multicolumn{8}{|l|}{ Synodontidae } \\
\hline Synodus intermedius & Piscivore & 1 & 2.8 & 0 & 0 & 0 & 0 \\
\hline \multicolumn{8}{|l|}{ Mugilidae } \\
\hline Mugil curema & Rov. Herbiv. & 0 & 0 & 0 & 4 & 2.8 & 0.2 \\
\hline \multicolumn{8}{|l|}{ Holocentridae } \\
\hline Holocentrus adscencionis & Mob. Invert. & 0 & 0 & 0 & 3 & 8.3 & 0.2 \\
\hline Myripristis jacobus & Planktivore & 0 & 0 & 0 & 1 & 2.8 & 0.1 \\
\hline \multicolumn{8}{|l|}{ Scorpaenidae } \\
\hline Scorpaena sp. & Carnivore & 1 & 2.8 & 0 & 0 & 0 & 0 \\
\hline \multicolumn{8}{|l|}{ Serranidae } \\
\hline Epinephelus adscensionis & Carnivore & 2 & 5.6 & 0.1 & 8 & 22.2 & 0.5 \\
\hline \multicolumn{8}{|l|}{ Carangidae } \\
\hline Caranx latus & Piscivore & 5 & 13.9 & 0.2 & 13 & 33.3 & 0.8 \\
\hline \multicolumn{8}{|l|}{ Lutjanidae } \\
\hline Ocyurus chysurus & Carnivore & 0 & 0 & 0 & 3 & 8.3 & 0.2 \\
\hline \multicolumn{8}{|l|}{ Gerreidae } \\
\hline Eucinostomus argenteus & Omnivore & 4 & 11.1 & 0.1 & 9 & 25 & 0.5 \\
\hline \multicolumn{8}{|l|}{ Hemulidae } \\
\hline Anisotremus moricandi & Mob. Invert. & 0 & 0 & 0 & 1 & 2.8 & 0.1 \\
\hline Anisotremus virginicus & Mob. Invert. & 7 & 11.1 & 0.2 & 13 & 25 & 0.8 \\
\hline Haemulon aurolineatum & Mob. Invert.Plankt. & 45 & 47.2 & 1.4 & 53 & 50 & 3.1 \\
\hline Haemulon parra & Mob. Invertiv. & 59 & 69.4 & 1.8 & 138 & 72.2 & 8.1 \\
\hline Haemulon plumierii & Mob. Invert. & 0 & 0 & 0 & 1 & 2.8 & 0.1 \\
\hline Haemulon squamipinna & Mob. Invert. & 2 & 5.6 & 0.1 & 0 & 0 & 0 \\
\hline \multicolumn{8}{|l|}{ Mullidae } \\
\hline Pseudupeneus maculatus & Mob. Invert. & 0 & 0 & 0 & 1 & 2.8 & 0.1 \\
\hline \multicolumn{8}{|l|}{ Chaetodontidae } \\
\hline Chaetodon striatus & Sessile Invert. & 0 & 0 & 0 & 2 & 5.6 & 0.1 \\
\hline \multicolumn{8}{|l|}{ Pomacentridae } \\
\hline Abudefduf saxatilis & Omnivore & 2482 & 100 & 75.1 & 629 & 97.2 & 36.8 \\
\hline Stegastes fuscus & Ter. Herbiv. & 377 & 100 & 11.4 & 389 & 97.2 & 22.7 \\
\hline Stegastes variabilis & Ter. Herbiv. & 21 & 36.1 & 0.6 & 25 & 50 & 1.5 \\
\hline \multicolumn{8}{|l|}{ Labridae } \\
\hline Halichoeres brasiliensis & Mob. Invert. & 42 & 75 & 1.3 & 59 & 83.3 & 3.5 \\
\hline Halichoeres poeyi & Mob. Invert. & 3 & 8.3 & 0.1 & 16 & 44.4 & 0.9 \\
\hline \multicolumn{8}{|l|}{ Scaridae } \\
\hline Sparisoma spp. & Rov. Herbiv. & 149 & 97.2 & 4.5 & 218 & 97.2 & 12.8 \\
\hline Labrisomidae & & & & & & & \\
\hline Labrisomus nuchipinnis & Carnivore & 12 & 27.8 & 0.4 & 10 & 25 & 0.6 \\
\hline Blennidae & & & & & & & \\
\hline Entomacrodus nigricans & Ter. Herbiv. & 7 & 13.9 & 0.2 & 1 & 2.8 & 0.5 \\
\hline Ophioblennius trinitatis & Omnivore & 19 & 41.7 & 0.6 & 24 & 47.2 & 1.4 \\
\hline Gobiidae & & & & & & & \\
\hline Coryphopterus glaucofraeunum & Planktivore & 16 & 33.3 & 0.5 & 6 & 16.7 & 0.4 \\
\hline Gobionellus stomatus & Mob. Invert. & 0 & 0 & 0 & 1 & 2.8 & 0.1 \\
\hline Acanthuridae & & & & & & & \\
\hline Acanthurus bahianus & Rov. Herbiv. & 0 & 0 & 0 & 2 & 2.8 & 0.1 \\
\hline Acanthurus chirurgus & Rov. Herbiv. & 4 & 11.1 & 0.1 & 18 & 33.3 & 1.1 \\
\hline Acanthurus coeruleus & Rov. Herbiv. & 40 & 58.3 & 1.2 & 61 & 72.2 & 3.6 \\
\hline Bothidae & & & & & & & \\
\hline Bothus lunatus & Carnivore & 5 & 8.3 & 0.2 & 0 & 0 & 0 \\
\hline Tetraodontidae & & & & & & & \\
\hline Sphoeroides testudineus & Mob. Invert. & 0 & 0 & 0 & 1 & 2.8 & 0.1 \\
\hline
\end{tabular}


Table 2. SIMPER percentages of the top seven fish species that most contributed to the differences between PT (presence of tourists) and AT (absence of tourists) periods.

\begin{tabular}{|c|c|c|c|}
\hline Species & $\begin{array}{l}\text { Trophic } \\
\text { group }\end{array}$ & $\begin{array}{c}\text { Dissimilarity } \\
(\%)\end{array}$ & $\begin{array}{l}\text { Cumulative } \\
\text { dissimilarity } \\
(\%)\end{array}$ \\
\hline Abudefduf saxatilis & Omnivore & 61.7 & 61.7 \\
\hline Stegastes fuscus & $\begin{array}{l}\text { Territorial } \\
\text { herbivore }\end{array}$ & 11.4 & 73.2 \\
\hline Sparisoma spp. & $\begin{array}{c}\text { Roving } \\
\text { herbivore }\end{array}$ & 5.9 & 79.1 \\
\hline Haemulon parra & $\begin{array}{c}\text { Mobile } \\
\text { invertivore }\end{array}$ & 5.3 & 84.4 \\
\hline Haemulon aurolineatum & $\begin{array}{c}\text { Mobile } \\
\text { invertivore }\end{array}$ & 2.8 & 87.2 \\
\hline Acanthurus coerulus & $\begin{array}{l}\text { Roving } \\
\text { herbivore }\end{array}$ & 2.3 & 89.5 \\
\hline Halichoeres brasiliensis & $\begin{array}{c}\text { Mobile } \\
\text { invertivore }\end{array}$ & 1.9 & 91.3 \\
\hline
\end{tabular}

Table 3. Summary of reef fish community structure variables (median $\pm \mathrm{SD}$ ) plus the Mann-Whitney U-test results of comparisons between the two periods, at presence of tourists (PT) and at absence of tourists (AT). Statistical significance: $\mathrm{p}<0.001(*)$.

\begin{tabular}{lccc}
\hline & PT & AT & $\begin{array}{c}\text { Mann-Whitney } \\
\text { U-test }\end{array}$ \\
\hline $\begin{array}{l}\text { Fish diversity (H') per } \\
\text { census }\end{array}$ & $0.9 \pm 0.34$ & $1.7 \pm 0.52$ & $\mathrm{Z}=-4.88^{*}$ \\
$\begin{array}{l}\text { Fish equitability (E) } \\
\text { per census }\end{array}$ & $0.4 \pm 0.17$ & $0.8 \pm 0.14$ & $\mathrm{Z}=-5.15^{*}$ \\
$\begin{array}{l}\text { Number of species per } \\
\text { census }\end{array}$ & $7.5 \pm 2.39$ & $9.0 \pm 2.21$ & $\mathrm{Z}=-3.18^{*}$ \\
$\begin{array}{l}\text { Total number of fish } \\
\text { per census }\end{array}$ & $73.0 \pm 65.64$ & $37.0 \pm 28.49$ & $\mathrm{Z}=3.82^{*}$ \\
\hline
\end{tabular}

the physiological and, possibly, the genetic constitution of fish communities, by promoting natural selection on the most aggressive individuals (Orams, 2002).

According to Ferreira et al. (2004), Northeastern Brazilian fish assemblages are dominated by roving herbivores and mobile invertivores. Yet, in our investigation we recorded a remarkable dominance of omnivores - a difference perhaps directly related to the type of supplementary food provided by tourists, which could act selecting species of that trophic group. Differential effects caused by food provisioning on trophic groups have also been found in the studies by Millazzo et al. (2005) and Cole (1994), who detected an increase in the abundance of carnivores and invertivores at their study sites. Furthermore, at the Picãozinho reef, sergeant majors were sighted actively following divers and snorkelers while feeding - a behavioral alteration also possibly triggered by food provisioning. Such behavioral shifts have been documented in the literature (Cole, 1994) and need to be further investigated.
Table 4. Differences in number of species and abundance (median of the number of individuals \pm SD) per census of the eight trophic groups between periods with the presence of tourists (PT) and absence of tourists (AT). Statistical significance: $\mathrm{p}<$ $0.001\left(^{*}\right) ; \mathrm{P}<0.05(* *), \mathrm{P}>0.05$ (ns, not significant).

\begin{tabular}{lccccc}
\hline \multicolumn{5}{c}{$\begin{array}{c}\text { Number of } \\
\text { species }\end{array}$} & \multicolumn{3}{c}{ Abundance (median \pm SD) } & \\
& PT & AT & PT & AT & $\begin{array}{c}\text { Mann-Whitney } \\
\text { U-test }\end{array}$ \\
\hline Carnivores & 4 & 3 & $0.0 \pm 1.75$ & $0.0 \pm 1.61$ & $\mathrm{Z}=-1.33^{\text {ns }}$ \\
M. invertivores & 6 & 10 & $4.2 \pm 7.02$ & $12.6 \pm 16.01$ & $\mathrm{Z}=-4.34^{*}$ \\
Omnivores & 3 & 3 & $76.4 \pm 23.56$ & $28.9 \pm 19.13$ & $\mathrm{Z}=5.19^{*}$ \\
Piscivores & 2 & 1 & $0.0 \pm 0.52$ & $0.0 \pm 1.83$ & $\mathrm{Z}=-2.04^{*}$ \\
Planktivores & 2 & 2 & $0.0 \pm 1.46$ & $0.0 \pm 0.99$ & $\mathrm{Z}=1.19^{\text {ns }}$ \\
R. herbivores & 3 & 5 & $5.5 \pm 7.30$ & $18.7 \pm 46.88$ & $\mathrm{Z}=-5.13^{*}$ \\
S. invertivores & - & 1 & $0.0 \pm 0.00$ & $0.0 \pm 0.83$ & $\mathrm{Z}=-0.41^{\text {ns }}$ \\
T. herbivores & 3 & 3 & $9.9 \pm 16.92$ & $24.1 \pm 16.86$ & $\mathrm{Z}=-3.06^{*}$ \\
\hline
\end{tabular}

Table 5. Size classe abundance (median of the number of individuals $\pm \mathrm{SD}$ ) per census within the two periods, with the presence of tourists (PT) and absence of tourists (AT). Statistical significance: $\mathrm{p}<0.001\left({ }^{*}\right) ; \mathrm{P}<0.05(* *), \mathrm{P}>0.05$ (ns, not significant).

\begin{tabular}{cccc}
\hline & \multicolumn{2}{c}{ Abundance (median \pm SD) } & Mann-Whitney \\
Size class $(\mathrm{cm})$ & PT & AT & U-test \\
\hline $1-5$ & $16.0 \pm 24.27$ & $7.0 \pm 15.03$ & $\mathrm{Z}=2.02^{* *}$ \\
$6-10$ & $20.0 \pm 25.69$ & $12.0 \pm 8.47$ & $\mathrm{Z}=2.95^{*}$ \\
$11-15$ & $21.5 \pm 27.89$ & $10.0 \pm 6.74$ & $\mathrm{Z}=3.07^{*}$ \\
$16-20$ & $7.5 \pm 11.17$ & $3.0 \pm 13.79$ & $\mathrm{Z}=1.71^{\mathrm{ns}}$ \\
$21-25$ & $0.0 \pm 2.00$ & $0.0 \pm 1.08$ & $\mathrm{Z}=0.87^{\mathrm{ns}}$ \\
\hline
\end{tabular}

Although the behavior of reef fish species could lead to a differential spatial distribution, probably triggered by olfactory cues and visual stimuli (Bond, 1979), it is very likely that uncontrolled tourist visitation contributed to the shift in the reef fish assemblage structure pattern at the study site. These shifts probably have started primarily as a mere concentration of $A$. saxatilis individuals in a short period of time, due to the supplementary feeding by the tourists. However, over the years this pattern probably has been incorporated to the fish assemblage structure of the reef, leading to the absolute dominance of A. saxatilis, even in the absence of tourists. This pattern was highlighted by Medeiros et al. (2007), which compared fish assemblages between Picãozinho and a neighboring reef submitted to a different level of tourism influence, and which presented a remarkably distinct fish assemblage structure.

It should be noted, however, that artisanal fishery - which has historically occurred in Picãozinho reef(Ilarri et al., 2007) - may have also played a role in structuring fish assemblage at the study site. Nevertheless, the negative consequences of fishing will be apparent regardless of tourist presence, thus, not influencing our results, where differences between AT and PT are strongly correlated to tourism alone. 
Reefs are vitally important to the tourism industry in Brazil, particularly in the Northeastern region of the country. Recognizing this, and the need to address the problems resulting from the increased use of reef resources, continued efforts to assess the condition of Brazilian reefs at local, regional, and national scales should be prioritized, particularly through long-term programs. Local management action at the study site should encompass, at minimum, setting areas closed for visitation, limiting the number of visitors, and monitoring of recreational activities.

\section{Acknowledgements}

We are indebted to Dr. Cláudio L. S. Sampaio for all his encouragement. Special thanks are due to the fisherman Dag for his help during field work, and to $\mathrm{CNPq}$ (Conselho Nacional de Desenvolvimento Científico e Tecnológico), CAPES (Coordenação de Aperfeiçoamento de Pessoal de Nível Superior) and PADI foundation for their essential financial support.

\section{Literature Cited}

Alevizon, W. 2004. Divers Feeding Fishes: A Continuing Issue in MPA Management. MPA News, 6(5): 1.

Allison, W. R. 1996. Snorkeller damage to coral reefs in the Maldive islands. Coral Reefs, 15: 215-218.

Bohnsack J. A. \& S. P. Bannerot. 1986. A stationary visual census technique for quantitatively assessing community structure of coral reef fishes. NOAA Technical Report, 41: 1-15.

Bond, C. E. 1979. Biology of Fishes. Philadelphia, Saunders College Publishing, 514p.

Carvalho-Filho, A. 1999. Peixes: costa brasileira. São Paulo, Editora Melro, 320p.

Cesar, H. 1996. Economic analysis of Indonesian coral reefs. Washington, D.C., The World Bank, 97p.

Cole, R. G. 1994. Abundance, size structure and diver-oriented behaviour of three large benthic carnivorous fishes in a marine reserve in northeastern New Zealand. Biological Conservation, 70: 93-99.

Deloach, N. \& P. Humann. 1999. Reef fish Behavior: Florida, Caribbean, Bahamas. Jacksonville, New World Publications, 359p.

Diedrich, A. 2007. The impacts of tourism on reef conservation awareness and support in coastal communities in Belize. Coral Reefs, 26: 985-996.

Ferreira, C. E. L., S. R. Floeter, J. L. Gasparini, B. P. Ferreira \& J. C. Joyeux. 2004. Trophic structure patterns of Brazilian reef fishes: a latitudinal comparison. Journal of Biogeography, 31: 1093-1106.

Field, J. G., K. R. Clarke \& R. M. Warwick. 1982. A practical strategy for analyzing multispecies distribution patterns. Marine Ecology Progress Series, 8: 37-52.

Harriot, V. J., D. Davis \& S. A. Banks. 1997. Recreational diving and its impact in marine protected areas in eastern Australia. Ambio, 26: 173-179.

Hawkins, J. P., C. M. Roberts, T. Van't Hof, K. De Meyer, J. Tratalos \& C. Aldam. 1999. Effects of recreational scuba diving on Caribbean coral and fish communities. Conservation Biology, 13: 888-897.
Hobson, E. S. 1975. Feeding patterns among tropical reef fishes. American Scientist, 63: 382-392.

Honey, M. 1999. Ecotourism and sustainable development: Who owns paradise? Washington, D.C., Island Press, 416p.

Humann, P. \& N. Deloach. 2002. Reef fish identification: Florida, Caribbean, Bahamas. Jacksonville, New World Publications, 481p.

Ilarri, M. I., A. T. Souza, P. R. Medeiros, R. G. Grempel \& C. L. S. Sampaio. 2007. Recife de Picãozinho: um aquário natural ameaçado. Ciência Hoje, 41: 70-72.

Medeiros, P. R., R. G. Grempel, A. T. Souza, M. I. \& C. L. S. Sampaio. 2007. Effects of recreational activities on the fish assemblage structure in a northeastern Brazilian reef. Pan-American Journal of Aquatic Sciences, 2(3): 288-300.

Millazzo, M., F. Badalamenti, T. Vega-Fernández \& R. Chemello. 2005. Effects of fish feeding by snorkellers on the density and size distribution of fishes in a Mediterranean marine protected area. Marine Biology, 146: 1213-1222.

Molina, W. F., O. A. Shibatta \& P. M. Galetti-Jr. 2006. Multivariate morphological analyses in continental and islands populations of Abudefduf saxatilis (Linnaeus) (Pomacentridae, Perciformes) of Western Atlantic. Pan-American Journal of Aquatic Sciences, 1(2): 49-56.

Nelson, J. 2006. Fishes of the World. John Wiley \& Sons Inc, New Jersey, 624p.

Newsome, D., A. Lewis, D. Moncrieff. 2004. Impacts and Risks associated with developing, but unsupervised, stingray tourism at Hamelin Bay, Western Australia. International Journal of Tourism Research, 6(5): 305-323.

Newsome, D., S. A. Moore, K. Dowling. 2002. Natural Area Tourism: Ecology, Impacts and Management. Clevedon, Channel View Publications, 340p.

Orams, M. B. 2002. Feeding wildlife as a tourist attraction: a review of issues and impacts. Tourism Management, 23: 281-293.

Perrine, D. 1989. Reef fish feedings: amusement or nuisance? Sea Frontiers, 35(5): 272-279.

Prior, M., R. Ormond, R. Hitchen \& C. Wormald. 1995. The impacts on natural resources of activity tourism: a case study of diving in Egypt. International Journal of Environmental Studies, 48: 201-209.

Randall, J. E. 1967. Food habits of reef fishes of the West Indies. Studies in Tropical Oceanography, 5: 665-847.

Roberts, L. \& V. J. Harriot. 1994. Recreational scuba diving and its potential for environmental impact in a marine reserve. Pp. 695704. In: Bellwood, O., H. Choat \& N. Saxena. (Eds.). Recent advances in marine science and technology 94. Honolulu, Pacon International, 754p.

Salvat, B. 1987. Human impacts on coral reefs: facts and recommendations. Antenne Museum EPHE, French Polynesia, 253p.

Samoilys, M. A. 1992. Review of the underwater visual census method developed by DPI/ACIAR project: visual assessment of reef fish stocks. Conference and Workshop Series, QC92006, Department of Primary Industries, 55p.

Vogt, H. 1996. The economic benefits of tourism in the marine reserve of Apo Island, Philippines. Sea Wind, 10: 13-19.

Young, P. S. 1986. Análise qualitativa e quantitativa da fauna associada a corais hermátipicos (Coelenterata: Scleractinia) nos recifes de João Pessoa, PB. Revista Brasileira de Biologia, 46: 99-126. 